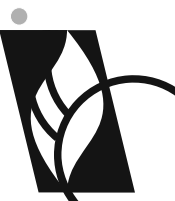

J O U R N A L

$\mathrm{O} F \bullet \mathrm{B} \mathrm{A} \mathrm{L} \mathrm{T} \mathrm{I} \mathrm{C}$

$S$ C I E N C E

E DUCATION

ISSN 1648-3898

Abstract. Raising young people aware of the need for science for peace is only possible with modern education that is based on science and enriches science with elements of peace. Accordingly, determination of perceptions of preservice teachers, who will bear the greatest responsibility in raising individuals, about the relationship between science and peace is of great importance. The aim of this research was

to develop a valid and reliable scale to measure preservice teachers' perceptions of the relationship between science and peace. A total of 253 preservice teachers, including 88 from the department of science teaching, 87 from the department of mathematics teaching and 78 from the department of primary school teaching, who were in their 4th year in the education faculty of Kocaeli University, Turkey, during the spring term of the academic year 2014-15, were recruited for this study. As a result of the factor analysis, Cronbach's alpha (á) reliability coefficient of the scale, consisting of four factors, including 'Communication and Intercultural Dialogue' (6 items), "Technological Developments' (6 items), 'Socio-Economic Developments' (7 items) and' Peace Education' (7 items), and

26 items, was found to be .93. The Scale for Perception of the Relationship between Science and Peace (SPSP) is the first unique scale developed to determine preservice teachers' perception of the relationship between science and peace.

Key words: science and peace, perceptions of preservice teachers, scale development.

Canan Dilek Eren Kocaeli University, Kocaeli, Turkey

\section{PRESERVICE TEACHERS' PERCEPTIONS DF THE RELATIONSHIP BETWEEN SCIENCE AND PEACE}

\section{Introduction}

From the time of the naturalists such as Copernicus, Kepler, Galileo and Newton up until today, the desire to dominate nature and obtain its information has been a major goal of science. While providing humans with information about nature, science satisfies their desire to process nature according to their demands through technology and dominate it. The desire to dominate nature launched an intense industrialization process with Industrial Revolution, which is a result of international competition and race to surpass. Although industrial revolution meant a healthy, comfortable life filled with technological toys with astonishing diversity to an unprecedented level in history for a large population (Mcclellan \& Dorn, 2013), its stakes and results were high. According to Gül (2013), 'urbanization and demographic challenges triggered by industrialization process led to rapid destruction of nature and disruption of wildlife, impaired the balance of nature in favor of people and caused environmental disasters almost impossible to remedy' (p.18). This has posed a threat to human life and social peace required for a healthy life.

As in nature, science has become a tool in the realization of a society's desire to dominate another society in the historical process. With technologies it has provided, it caused wars and other areas of cross-border competition acquire various dimensions. In the new world order, a new era, where wars are called'total war', has begun. In total war, operations are all over the world; there is no limit to war (Wikipedia, 2015). Therefore, wars have become more formidable. Nuclear and chemical weapons, missiles and radar tracking devices are of great importance in terms of both defense and attack, giving rise to great changes for the implementation of war (Koç, 2013). Innocent people lose their lives in non-stop wars in most parts of the world, while some countries support the developments in the war industry for the sake of their economic interests. Developed countries control the majority of the world's resources in this regard, while the least developed countries are 
faced with an environment lacking basic human needs (Kaypak, 2012). As a result, all these developments have become a threat to world peace.

Peace manifests itself in individual and social relations, and in our era, have also become universal and globally shared values (Balcı \& Katılmış, 2012). In an environment where there is no peace, all natural and human elements and vital processes are under threat so presence of national and international peace and preserving it are of paramount importance. To ensure presence of peace and preserve it, scientific developments that will minimize such threats in terms of quality and quantity and ensure optimum use of natural resources in order to make them sustainable are required. Briefly, it is necessary to contribute to peace by making science for peace.

International organizations who believe in the necessity of building peace through science continue their activities on a global scale. One of them, the United Nations Educational, Scientific and Cultural Organization (UNESCO) has continued its operations since 1945 in order to contribute to the establishment of global peace through education, science, culture and information ("Introducing UNESCO," 2015). "Science for Peace", which is a project being carried out to help and pioneer building peace in the light of scientific data was launched in 2009 and it continues its activities in the international platform with over 2500 members (Science for Peace, 2015). Science for Peace and Security (SPS) Committee of North Atlantic Treaty Organization (NATO) is the primary NATO committee that supports practical cooperation in the area of civil science and innovation ("The Science for Peace and Security Programme," 2015). This committee also contributes to NATO's mission by supporting scientific projects for peace.

With article 26/2 of United Nations Universal Declaration of Human Rights, which says “Education shall promote understanding, tolerance and friendship among all nations, racial or religious groups, and shall further the activities of the United Nations for the maintenance of peace." ("Universal Declaration of Human Rights," 2015) the importance of education is referred to for peace and for maintaining peace. Raising young people aware of the need for science for peace is only possible with modern education that is based on science and enriches science with elements of peace. Accordingly, determination of perceptions of preservice teachers, who will bear the greatest responsibility in raising individuals, about the relationship between science and peace is of great importance.

\section{Importance of the Research}

In the literature, there are several studies on the concept of science, including perception of the concept of science (Muşlu and Macaroğlu, 2006), attitudes towards science (Mıhladız and Duran, 2010; Erdoğan, 2013), preservice teachers' perceptions of scientists (Ünver, 2010; Çermik, 2013; Şenel and Aslan, 2014). Studies on the concept of peace include attitudes towards peace issues (Aktaş and Safran, 2013), influence of the school in raising awareness about peace (Joseph, 2012), perception of peace concept (Katılmış et al., 2011; İmamoğlu and Bayraktar, 2014), creating peace based programs (Ghaderi, 2011), peace education (Gültekin and Gültekin, 2013; Paderanga, 2014) and global citizenship education for world peace and security (Farahani, 2014). Although science and peace were individually addressed and studied, there's no study in the literature that investigated perception of the relationship between science and peace. Thus, this scale, which can determine preservice teachers' perceptions of the relationship between science and peace, is the first in the area, and it is expected to contribute to the literature in terms of its effort to reveal preservice teachers' perceptions of the relationship between science and peace.

\section{Aim of Research}

In this context, the main aim of research is to develop an instrument for measuring preservice teachers' perceptions of the relationship between science and peace. In the literature, there's no report of a scale that can measure individuals' perceptions of the relationship between science and peace. Therefore, development of "the Scale for Perception of the Relationship between Science and Peace" applicable to teachers is expected to bridge an important gap in the area. Determining preservice teachers' perceptions of the relationship between science and peace will provide guidance to experts of the area and educators.

\section{Methodology of Research}

A mixed-methods sequential exploratory design was used to develop and test the reliability and validity of The Scale for Perception of the Relationship between Science and Peace (SPSP). The mixed-methods sequential exploratory 
design consists of two distinct phases: qualitative followed by quantitative data collection and analysis (Creswell et al. 2003). According to Cresswell (2012), this design is useful when developing and testing a new instrument. Based upon this design, in the first phase, qualitative methods (document analysis and expert views) were used to generate an item pool. In the second phase, quantitative methods (factor analysis and reliability) were used to evaluate the construct validity and reliability of SPSP.

\section{Sample}

The research sample consisted of a total of 253 preservice teachers, including 88 from the department of science teaching, 87 from the department of mathematics teaching and 78 from the department of primary school teaching, who were in their 4th year during the spring term of the academic year 2014-15. Comrey and Lee (1992) offered a rough rating scale for adequate sample sizes in factor analysis: $100=$ poor, $200=$ fair, $300=$ good. Information about the participants, including gender, department and type of study, is given in Table 1.

Table1. Data relating to the participants of the research.

\begin{tabular}{|c|c|c|c|c|c|}
\hline \multirow{2}{*}{ DEPARTMENT } & \multicolumn{2}{|c|}{ Female } & \multicolumn{2}{|c|}{ Male } & \multirow{2}{*}{ TOTAL } \\
\hline & n & $\%$ & n & $\%$ & \\
\hline Science Teaching, daytime education & 38 & 15.02 & 5 & 1.98 & 43 \\
\hline Science Teaching, evening education & 41 & 16.21 & 4 & 1.58 & 45 \\
\hline Mathematics Teaching, daytime education & 40 & 15.81 & 11 & 4.35 & 51 \\
\hline Mathematics Teaching, evening education & 25 & 9.88 & 11 & 4.35 & 36 \\
\hline Primary School Teaching, daytime education & 33 & 13.04 & 7 & 2.77 & 40 \\
\hline Primary School Teaching, evening education & 33 & 13.04 & 5 & 1.98 & 38 \\
\hline Total & 210 & 83.00 & 43 & 17.00 & 253 \\
\hline
\end{tabular}

\section{Data Collection Tools}

The scale for perception of the relationship between science and peace (SPSP) was developed to determine preservice teachers' perceptions of the relationship between science and peace (The scale in annex). For this purpose, a literature review was performed and theoretical framework was determined. An item pool was generated in the light of accessible information and texts obtained from preservice teachers' answers to open-ended questions.

During the preparation stage of the guidelines, opinions of the two assessment and evaluation experts and the three field experts were obtained to measure the perception of the relationship between science and peace, and a 5-point Likert scale was developed. Guidelines and publication of the scale were performed accordingly. Rating and scoring of the items were as follows:"I strongly disagree (1)", "I disagree (2)","I neither agree nor disagree (3)","I Agree (4)", "I strongly agree (5)". For negative statements, completely opposite of the abovementioned rating was performed. High score obtained from the scale indicates that preservice teachers' perceptions of the relationship between science and peace is positive.

Attention was paid to ensuring that the scale items are simple, plain and straightforward. After the scale items were prepared, 2 experts on Turkish language teaching were consulted to check if the sentences are clear and bear a single meaning in terms of their compliance with grammar and clarity. In line with the opinions of these experts, the sentences in the items were made compliant with Turkish language.

The items in draft form of the scale were reviewed by 3 experts from the department of science teaching. They were asked to assess each of the items in terms of whether the items in the draft form are in compliance with the subject they're intended to measure, indicate their suggestions on the relevant items and print their suggestions for new items, if any. In accordance with the experts' opinions, necessary corrections were made and the scale reached its final form for a trial.

Draft SPSP was implemented on 15 preservice teachers from the department of science teaching in order to receive feedback on the clarity and implementation period of the items. Those who completed SPSP were in- 
terviewed about what they think about the clarity of the scale items and adequacy of the time for answering the questions. Minor adjustments were made in the structure of sentences only in 2 items and the scale became ready to be implemented on a large group.

Implementation was carried out on the specified study group. Reliability and validity analyses were performed with the obtained data.

\section{Data Analysis}

The data obtained in the research were analysed using SPSS 11.5 and Lisrel 8.7 software packages. Exploratory factor analysis (EFA) and confirmatory factor analysis (CFA) were performed for construct validity of SPSP. In this way, it was assessed to what extent the resultant four-factor-measurement-model complies with the collected data. Within the scope of reliability studies, item-total correlation coefficients and Cronbach's alpha internal consistency coefficients were calculated.

\section{Results of Research}

\section{Exploratory Factor Analysis}

Exploratory factor analysis was performed in order to reveal factor pattern of the measurement tool with 57 items intended to measure preservice teachers' perceptions about the relationship between science and peace.

Before the analysis, Kaiser-Meyer-Olkin (KMO) measure of sampling adequacy test (Kaiser, 1974) was applied to test if sample size is suitable for factorization. At the end of the analysis, KMO value was determined to be 0.94 . In line with this finding, it was concluded that the sample size is "perfect" for doing a factor analysis (Tabachnick \& Fidell, 2007). In addition, Bartlett sphericity test (Bartlett, 1954) was performed in order to test whether the data has a multivariate normal distribution. The chi-square $\left(\chi^{2}\right)$ value obtained from the analysis was found to be significant $\quad\left(\chi_{(253)}^{2}=4628.312 ; \mathrm{p}<.01\right)$. According to the results shown in Table 2 , data were assumed to have a multivariate normal distribution.

Table 2. KMO and Bartlett Test Analysis Results for the Scale for Perception of the Relationship between Science and Peace.

\begin{tabular}{lcc}
\hline \multicolumn{2}{c}{ Kaiser-Meyer-Olkin Measure of Sampling Adequacy } & $\mathbf{0 . 9 4 7}$ \\
\hline Bartlett's Sphericity Test & Approx. Chi-Square & 4628.312 \\
\cline { 2 - 3 } & $\mathrm{df}$ & 595 \\
\cline { 2 - 3 } & Sig. & 0.0001 \\
\hline
\end{tabular}

Principal component method has been selected as the factorization method to reveal the factor pattern of SPSP. Where it is difficult to decide to which component the items belong to, direct oblimin was used as the rotation method to find an easier to read or more appropriate factor structure without disrupting the explained variance (Büyüköztürk, 2004). As a result of the analysis, it was seen that there are four factors with an eigenvalue greater than 1 for 57 items.

Factor load is a variable which shows to what extent the variables, in combination with other variables in the respective factor, measure the same factor. In factor analysis, factor loads of the variables should be minimum 0.30, while 0.40 and higher values are also preferred in general (Floyd \& Widaman, 1995). Based on this opinion, acceptable factor load value was specified as .50. Items in which the difference of loading in more than one factor is less than 0.20 were removed from the scale. These processes were repeated until obtaining a suitable structure with 4 factors and 26 items. Load values of these items are in the range of .50 to .80 .

In view of the scree plot in Figure 1, it is noteworthy that the point where the curve shows a rapid decline is the point where the fourth factor is located. As a result, it was concluded that SPSP should have 4 factors. 


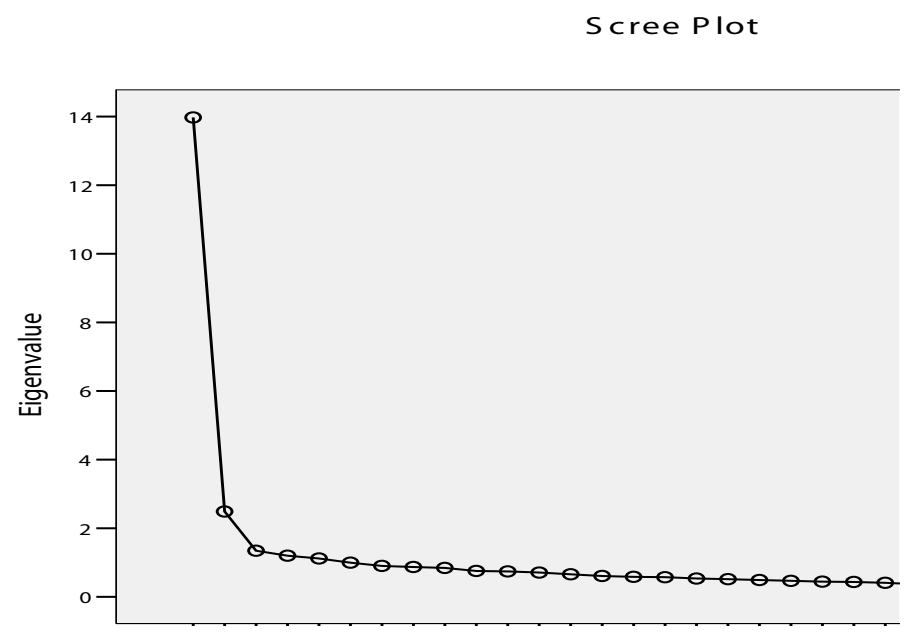

Figure 1. Scree Plot for SPSP.

Important values related to 4 factors obtained as a result of factor analysis are shown in Table 3. Table 3 proves that factor loads of the items are well above the acceptable values. In addition, the contribution of factors to the total variance (\%) are $39.9,7.1,3.8$ and 3.4 for the $1^{\text {st }}, 2^{\text {nd }}, 3^{\text {rd }}$ and $4^{\text {th }}$ factors, respectively. Total contribution of the established 4 factors to the variance is $54.3 \%$. A high variance percentage means that the Scale for Perception of the Relationship between Science and Peace has a strong factor structure.

Table 3. Principal Component Analysis.

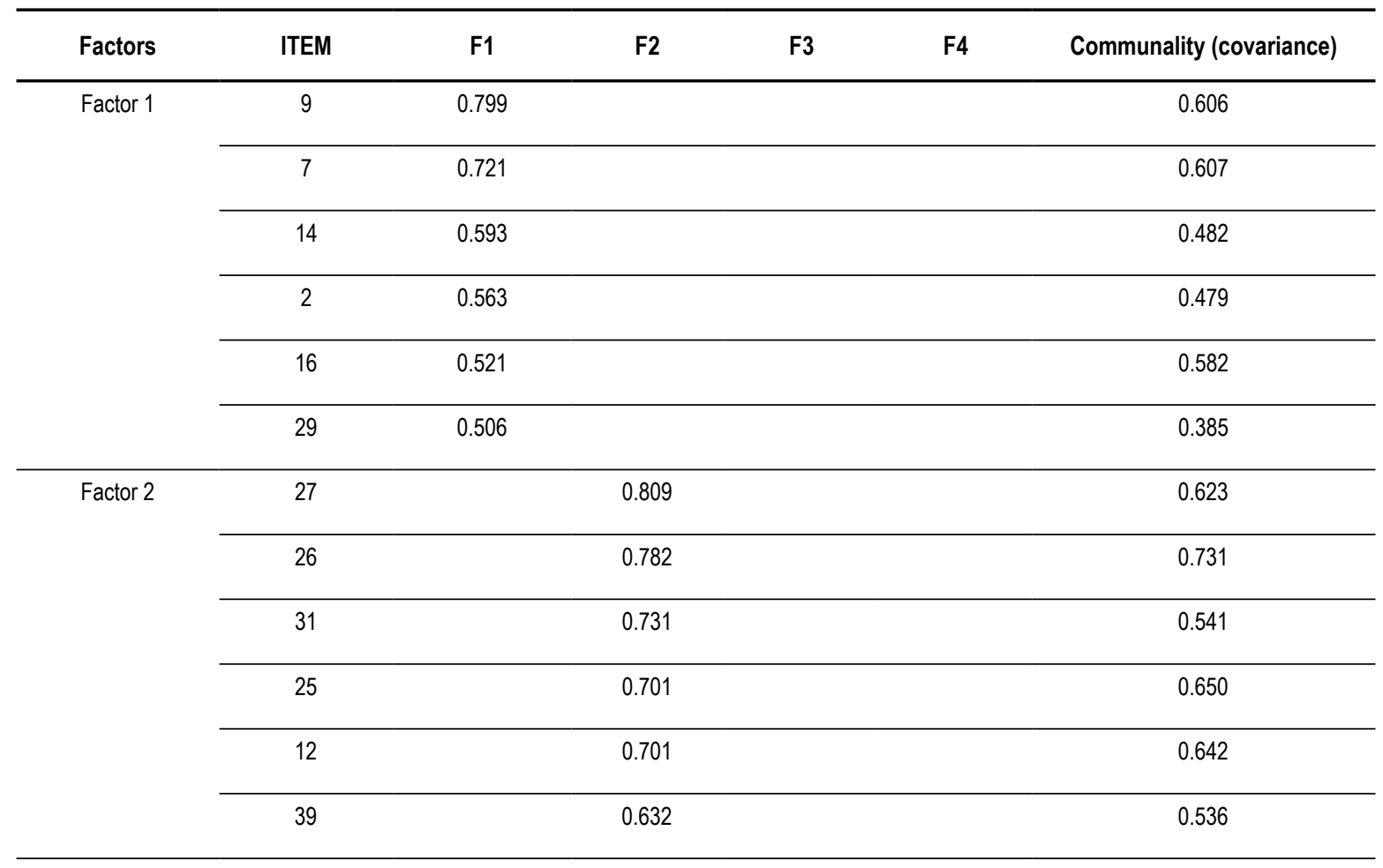




\begin{tabular}{|c|c|c|c|c|c|c|}
\hline Factors & ITEM & F1 & F2 & F3 & F4 & Communality (covariance) \\
\hline \multirow[t]{7}{*}{ Factor 3} & 19 & & & -0.780 & & 0.565 \\
\hline & 21 & & & -0.717 & & 0.598 \\
\hline & 17 & & & -0.614 & & 0.478 \\
\hline & 36 & & & -0.569 & & 0.541 \\
\hline & 50 & & & -0.564 & & 0.480 \\
\hline & 56 & & & -0.518 & & 0.471 \\
\hline & 53 & & & -0.512 & & 0.542 \\
\hline \multirow[t]{8}{*}{ Factor 4} & 45 & & & & 0.694 & 0.492 \\
\hline & 40 & & & & 0.613 & 0.429 \\
\hline & 57 & & & & 0.548 & 0.495 \\
\hline & 43 & & & & 0.548 & 0.494 \\
\hline & 55 & & & & 0.526 & 0.587 \\
\hline & 54 & & & & 0.509 & 0.632 \\
\hline & 42 & & & & 0.507 & 0.629 \\
\hline & Eigenvalue & 13.974 & 2.488 & 1.344 & 1.200 & \\
\hline \multicolumn{2}{|c|}{ Variance Explained (\%) } & 39.927 & 7.107 & 3.841 & 3.429 & \\
\hline \multicolumn{2}{|c|}{ Total Variance Explained (\%) } & 54.304 & & & & \\
\hline \multicolumn{2}{|c|}{ Cronbach's a (\%) } & 82.7 & 86.5 & 84.3 & 83.8 & \\
\hline
\end{tabular}

It is apparent from Table 3 that the rates by which each item explains the variance in the common factor together (covariance) ranges between 0.38 and 0.73 . This also shows that common factor variances of the items are generally high.

As a result of the factor analysis, variables that are grouped under 4 factors have been identified. Information on these factors is as follows.

The first factor consists of 6 items, including item 9, 7, 14, 2, 16 and 29. Eigenvalue of these items is 13.97, with their factor load values ranging from 0.50 to 0.79 . This factor includes clauses about communication and intercultural dialogue. Therefore, it was deemed appropriate to designate this factor 'Communication and intercultural dialogue'. One of the items in this factor is 'Item 14: Developments in communication technology override borders in the virtual environment so science increases intercultural communication and contributes to world peace.

The second factor consists of 6 items, including item 27, 26, 31, 25, 12 and 39. Eigenvalue of these items is 2.48 , with their factor load values ranging from 0.63 to 0.80 . This factor includes clauses about technological developments and it was therefore designated 'technological developments'. One of the items in this factor is 'Item 25: Technological developments increase economic imbalance between countries with different levels of development so science is an obstacle to communities living in peace".

The third factor consists of 7 items, including item 19,21, 17, 36, 50, 56 and 53 . Eigenvalue of these items is 
1.34 , with their factor load values ranging from 0.51 to 0.78 . The items in this factor comprise clauses related to socio-economic developments so it was deemed appropriate to designate this factor'socio-economic developments'. One of such clauses in this factor is ' item 17: Science prevents water wars and contributes to peace by providing solutions to diminishing water resources".

The fourth factor consists of 7 items, including item 45, 40, 57, 43, 55, 54 and 42. Eigenvalue of these items is 1.2 , with their factor load values ranging from 0.50 to 0.69 . The designation 'peace education' was thought to describe the factor in the most appropriate way. One of the items in this factor, namely 'item 43: Science helps people understand and become aware of natural phenomena, causing them to stay away from war." provides a better understanding of the designation of the factor.

\section{Confirmatory Factor Analysis}

Confirmatory factor analysis was used to test the accuracy of the model consisting of 26 items obtained by exploratory factor analysis. Confirmatory factor analysis was conducted using Lisrel 8.7 software package.

Suggestions for modifying the model were examined and the modification which could contribute to $x^{2}$ values was found to be between item 12 (scientific developments cause wars by increasing raw material and market demand so it cannot provide a contribution to peace) and item 25 (Technological developments increase economic imbalance between countries with different levels of development so science is an obstacle to communities living in peace). After such modification was made and the analysis was repeated, the modification made a significant contribution to chi-square $\left(\mathrm{x}^{2}\right)$. Such modification was also shown on the model.

Matsunaga (2010) suggests that the results of confirmatory factor analysis should be evaluated in the light of chi-square ( ) goodness of fit value, root mean square error of approximation (RMSEA), comparative fit index (CFI) and standardized root mean square residual (SRMR). Büyüköztürk et al. (2012) states that chi-square fit index is not a statistic evaluated on its own and suggests that chi-square value should be evaluated by dividing it by the degree of freedom (df). Following the modification, when fit indices of the measurement model was examined, $p$ value related to value $\left({ }_{(292)}=1231.64\right)$ was found to be significant $(p<.01)$. When the model was evaluated with respect to the ratio of chi-square to degree of freedom ( / sd $=4.21$ ), the fit was found to be at an acceptable level according to the result obtained (Marsh \& Hocevar, 1985). Based on the results obtained, it was confirmed that the scale for perception of the relationship between science and peace has a 4-dimensional structure.

Figure-2 presents the resultant path diagram from confirmatory factor analysis of these four factors. Each path shows the weight or load of representation of latent variable in observed variable (Çokluk et al, 2012). As illustrated in the figure, $t$ values regarding the explanation of observed variables by latent variables are significant at the .01 level. 


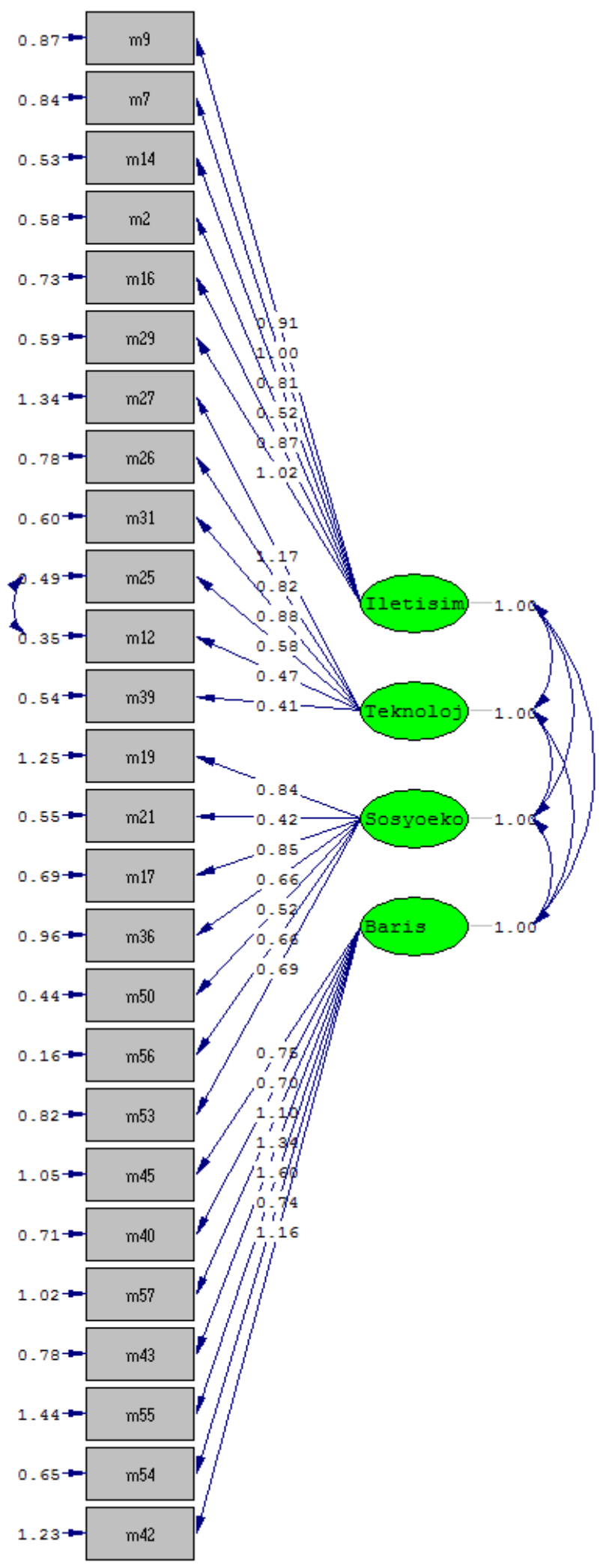

Figure 2. The path diagram of SPSP. 


\section{Reliability}

Individual Cronbach's alpha reliability coefficients were calculated for each subscale and the whole scale in order to demonstrate internal consistency of the scale, developed to determine preservice teachers' perceptions of the relationship between science and peace. As a result of the statistical analyses performed to question the consistency of the scale, the resulting Cronbach's alpha (a) reliability coefficient was .93. In addition, Cronbach's alpha (a) reliability coefficients of the subscales of SPSP were $.82, .86, .84$ and .83 for $1 \mathrm{st}$, 2nd, 3rd and 4 th subscales, respectively. The corrected item-total correlations calculated for each factor to determine to what extent the scale items distinguish preservice teachers in terms of their perceptions of the relationship between science and peace ranged from .45 to .70 (Table 4).

Table 4. Results of Item Analysis of SPSP.

\begin{tabular}{cccc}
\hline Factor items & $\begin{array}{c}\text { Corrected item- } \\
\text { total correlation }\end{array}$ & Factor items & $\begin{array}{c}\text { Corrected item-total } \\
\text { correlation }\end{array}$ \\
\hline Communication and intercultural dialogue & & Socio-economic developments & .58 \\
\hline 2 & .57 & 17 & .53 \\
7 & .59 & 19 & .61 \\
9 & .54 & 21 & .61 \\
14 & .57 & 36 & .59 \\
16 & .67 & 50 & .67 \\
29 & .51 & 53 & .61 \\
\hline Technological developments & & 56 & .48 \\
12 & .60 & Peace education & .70 \\
25 & .63 & 40 & .51 \\
26 & .60 & 42 & .46 \\
31 & .45 & 43 & .66 \\
39 & .49 & 45 & .63 \\
& .55 & 54 & .53 \\
\hline
\end{tabular}

\section{Discussion}

The aim of this research was to develop a valid and reliable scale to measure preservice teachers' perceptions of the relationship between science and peace. Exploratory and Confirmatory factor analyses were used to evaluate the construct validity. Reliability of the scale was tested via Cronbach's Alpha and The corrected item-total correlation.

Exploratory factor analysis was performed in order to reveal factor pattern of the measurement tool with 57 items intended to measure preservice teachers' perceptions about the relationship between science and peace. As a result of the analysis, a suitable structure with 4 factors and 26 items was obtained. Load values of these items are in the range of .50 to .80 . A factor load of 0.50 and higher is considered very good value (Streiner, 1994; Costello \& Osborne, 2005). Total contribution of the established 4 factors to the variance is $54.3 \%$. An explained variance less than $60 \%$ is generally regarded as unsatisfactory (Hair, Anderson, Tatham \& Black, 1998), however, this ratio is considered satisfactory for social sciences (Msweli \& Wushe, 2014). A high variance percentage means that the Scale for Perception of the Relationship between Science and Peace has a strong factor structure.

Confirmatory factor analysis was used to test the accuracy of the model consisting of 26 items obtained by exploratory factor analysis. The RMSEA value was .10, which demonstrates that the fit is mediocre (Hu \& Bentler, 1999). When conformity indexes were examined, CFI value was .95, which indicates a good fit (Kline, 2011; Hu \& Bentler, 1999). SRMR, which is also another fit index, was .08, which is another finding that demonstrates the good fit (Hu 
\& Bentler, 1999; Matsunaga, 2010; Worthington \&Whittaker, 2006). Based on the results obtained, it was confirmed that the scale for perception of the relationship between science and peace has a 4-dimensional structure.

Individual Cronbach's alpha reliability coefficients were calculated for each subscale and the whole scale in order to demonstrate internal consistency of the scale. As a result of the statistical analyses performed to question the consistency of the scale, the resulting Cronbach's alpha (a) reliability coefficient was .93. Nunnally (1967) argues that if reliability of a scale depending on alpha (a) coefficient is $.80 \leq a<.100$, the scale is a highly reliable scale. In this case, the items in SPSP can be said to be consistent with each other and show the same characteristic.

The corrected item-total correlations calculated for each factor to determine to what extent the scale items distinguish preservice teachers in terms of their perceptions of the relationship between science and peace ranged from .45 to .70. According to Büyüköztürk (2006), the items with item-total correlation of .30 and higher distinguish individuals well. According to all these results, SPSP is reliable to the extent acceptable for research in social sciences.

Findings of validity and reliability studies indicated that The Scale for Perception of the Relationship between Science and Peace (SPSP) sets a valid and reliable tool for determining preservice teachers' perceptions of the relationship between science and peace.

\section{Conclusions}

In this research, a scale to determine preservice teachers' perceptions of the relationship between science and peace was developed. The scale is a four-factor scale. The four-factor structure determined by EFA was also examined by CFA and the calculated fit statistics were found to satisfy the criteria values specified in the method. This result was interpreted as that the scale has a good model-data fit.

A reliable 26-item scale with a Cronbach's alpha (a) reliability coefficient of .93, consisting of four factors in total, was obtained. The resulting factors were designated as communication and intercultural dialogue, technological developments, socio-economic developments and peace education.

The Scale for Perception of the Relationship between Science and Peace (SPSP) allows determination of preservice teachers' perceptions of the relationship between science and peace. It may also be adapted for primary and secondary school students and their perceptions of the relationship between science and peace can be determined. Using this scale, a comprehensive study that will determine perceptions of preservice teachers studying at all education faculties across Turkey about the relationship between science and peace can be conducted.

The results of this study demonstrated that this scale is a valid and reliable scale and it's the first scale developed to determine preservice teachers' perceptions of the relationship between science and peace.

\section{References}

Aktaş, Ö., \& Safran, M. (2013). An evaluation of the views of secondary education students over the concepts of war and peace in terms of different variables. International Periodical For The Languages, Literature and History of Turkish or Turkic, 8 (8), $1587-1619$

Balcı, A., \& Katılmış, A. (2012). Analysis of perceptions of geography teacher candidates' about the united nations permanent member states' role in peacemaking. Marmara Geographical Review, 25, 390-408.

Bartlett, M.S. (1954). A note on the multiplying factors for various chi square approximations. Journal of the Royal Statistical Society, 16 (Series B), 296-298.

Büyüköztürk, S. (2004). Veri analizi el kitabı. [Data Analysis Manual.] Ankara: PegemA publishing.

Büyüköztürk. S. (2006). Sosyal bilimler için veri analizi el kitabı. [Data analysis handbook for social sciences.] Ankara: PegemA publishing.

Büyüköztürk, S., Çokluk, O., \& Köklü, N. (2012). Sosyal bilimler için istatistik. [Statistics for social sciences.] Ankara: PegemA publishing.

Comrey, A. L., \& Lee, H. B. (1992). A first course in factor analysis. Hillsdale, NJ: Erlbaum.

Çermik, H. (2013). A scientist created in the picture that pre-service teachers have in their minds. Pamukkale University Journal of Education, 33 (1), 139-153.

Çokluk, O., Sekercioglu, G., \& Büyüköztürk, S. (2012). Sosyal bilimler için çok değişkenli istatistik SPSS ve LISREL uygulamaları. [Multivariate statistics for the social sciences SPSS and LISREL applications.] Ankara: PegemA publishing.

Costello A.B. \& Osborne J.W. (2005). Best practices in exploratory factor analysis: Four recommendations for getting the most from your analysis. Practical Assessment Research \& Evaluation, 10 (7), 1-9.

Creswell, J. W., Plano Clark, V. L., Gutmann, M., \& Hanson, W. (2003). Advanced mixed methods research designs. In A. Tashakkori \& C. Teddlie (Eds.), Handbook of mixedmethods in social \& behavioral research. Thousand Oaks, CA: Sage. 
Creswell, J. W. (2012). Educational research: Planning, conducting, and evaluating quantitative and qualitative approaches to research. Boston: Pearson

Erdoğan, S. (2013). Gifted girls' scientific attitudes and images of scientists. Hasan Ali Yücel University Journal of Education Faculty, $19(1), 125-142$.

Farahani, M.F. (2014). The role of global citizenship education in world peace and security. Procedia - Social and Behavioral Sciences, 116 (2014), 934-938.

Floyd, F.J., \& Widaman, K.F. (1995). Factor analysis in the development and refinement of clinical assessment instruments. Psychological Assessment, 7 (3), 286-299.

Ghaderi, M. (2011). Peace-based curriculum based on the theories of "difference" and "similarity". Procedia Social and Behavioral Sciences, 15 (2011), 3430-3440.

Gül, F. (2013). Environmental problems and philosophy in the context of human-nature relationship. Pamukkale University Journal of Social Sciences Institute, 14, 17-21.

Gültekin, B., \& Gültekin, T. (2013). Communication models and sensitivity approaches for intercultural peace education. Procedia - Social and Behavioral Sciences, 106 (2013), 641-650.

Hair, J.F., Tatham, R.L., Anderson, R.E., \& Black, W.C. (1998). Multivariate data analysis, New Jersey: Prentice Hall.

Hu, L-T., \& Bentler, P.M. (1999). Cutoff criteria for fit indexes in covariance structure analysis: Conventional criteria versus new alternatives. Structural equation modeling: A Multidisciplinary Journal, 6 (1), 1-55.

Introducing UNESCO. (2015). Retrieved from http://en.unesco.org/about-us/introducing-unesco

İmamoğlu, H.V., \& Bayraktar, G. (2014). Comparison of Turkish and Hungarian students' perceptions towards Peace. Karabük University Journal of Social Sciences Institute, 4 (1), 20-44.

Joseph, J. (2012). How the schooling environment shapes the consciousness of scholars towards peace and war. Procedia-Social and Behavioral Sciences, 55, $697-706$.

Kaiser, H. (1974). An index of factorial simplicity. Psychometrika, 39, 31-36.

Katılmış, A., Kop, Y., \& Çelik, H. (2011, May 7). 5th grade students' perceptions of peace concept as a merit: A case study conducted in Istanbul, Kars and Sakarya. Paper presented at the 10th Classroom Teaching Education Symposium, Cumhuriyet University.

Kaypak, Ş. (2012). An ethical approach to environmental peace. The International Journal of Economic and Social Research, 8 (1), $1-30$.

Kline, R.B. (2011) Principles and practice of structural equation modeling. New York: The Guilford Press.

Koç, E. (2013). Human-Being responsibilty (Ethic conscience) in the era of science and technology. Atatürk University Journal of Social Sciences Institute, $17(2), 1-13$.

Marsh, H.W., \& Hocevar, D. (1985). Application of confirmatory factor analysis to the study of self-concept: First-and higher-order factor models and their invariance across groups. Psychological Bulletin, 97 (3), 562-582.

Matsunaga, M. (2010). How to factor-analyze your data right: Do's, don'ts, and how-to's. International Journal of Psychological Research, 3(1), 97-110.

Mcclellan, J. E., \& Dorn, H. (2013). Science and technology in world history (H.Yalçın, Trans.). Ankara: Arkadaş yayınevi. (Original work published 1999)

Mıhladız, G., \& Duran, M. (2010). Investigation of primary school students' attitudes towards science in terms of demographic variables. Mehmet Akif Ersoy University Journal of Education Faculty, 10 (20), 100 - 121.

Msweli, P., \& Wushe, T. (2014). An analysis of corporate community engagement in Zimbabwe. Environmental Economics, 5 (4), 44-51.

Muşlu, G., \& Macaroğlu, E. (2006). Elementary school students' perceptions of science and scientific processes: A Qualitative Study. Educational Sciences: Theory \& Practice, 6 (1), 225-229.

Nunnally, J. C. (1967). Psychometric theory. New York: Mc -Graw Hill.

Paderanga, L.D. (2014). Classroom video conferencing: Its contribution to peace education. Procedia-Social and Behavioral Sciences, 123 (2014), 113-121.

Science for Peace (n.d.). Retrieved June 7, 2015, from http://scienceforpeace.ca/

The Science for Peace and Security Programme. (2015). Retrieved from http://www.nato.int/cps/en/natolive/78209.htm

Şenel, T., \& Aslan, O. (2014). The metaphoric perceptions of preservice early childhood teachers conceptions on science and scientist. Mersin University Journal of the Faculty of Education, 10 (2), 76-95.

Streiner, D. L. (1994). Figuring out factors: The use and misuse of factor analysis. Canadian Journal of Psychiatry, 39 (3), $135-140$.

Tabachnick, B. G., \& Fidell, L. S. (2007). Using multivariate statistics. Boston: Allyn and Bacon.

Universal Declaration of Human Rights. (2015). Retrieved from http://www.unicef.org/turkey/udhr/_gi17.html

Ünver, A. (2010). Perceptions of Scientists: A comparative study of fifth graders and fourth year student teachers. Necatibey Faculty of Education Electronic Journal of Science and Mathematics Education, 4(1),11-28.

Wikipedia (n.d.). Retrieved June 2, 2015, from https://tr.wikipedia.org/wiki/total war

Worthington, R.L., \& Whittaker, T.A.(2006). Scale development research: A content analysis and recommendations for best practices. The Counseling Psychologist, 34 (6), 806-838. 


\section{THE SCALE FOR PERCEPTION OF THE RELATIONSHIP BETWEEN SCIENCE AND PEACE (SPSP) Dear Pre-Service Teachers, \\ Please indicate your level of agreement with the following expressions by putting a cross $(X)$ in the boxes. Thank you for your contribution to my study with your responses.}

\section{Dr. Canan DILEK EREN}

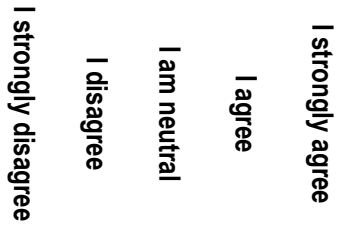

Science is a universal language. Therefore, it is the most appropriate approach for keeping the peace in the world.

Science leads to peace through progress in communication technologies and providing inter-cultural communication.

Science makes contribution to peace by bringing together people from various languages, religions, and races.

Scientific developments cannot contribute to peace since they increase the need for raw materials and markets, thereby causing wars.

Science contributes to the world peace by increasing intercultural communication as the developments in communication technologies invalidate the boundaries in the virtual environments.

Science education contributes to solving social problems peacefully by improving the critical thinking skills of individuals.

Science contributes to peace through generating solutions for depleted water resources, thereby preventing water wars.

Science creates a peace environment by eliminating the poverty through products to be used in agriculture.

Scientific developments contribute to peace by minimizing the natural resources competition among communities.

Science prevents communities from living in peace by increasing the economic inequality between different countries with different levels of development through technological advances.

Science prevents communities from living in peace by increasing the developmental inequality between different countries through developments in communication technologies.

Science prevents communities from living in peace by increasing wars through advances in war technology

Science education contributes to peace by positively improving individuals' perspectives towards human rights.

Scientific developments lead to wars for healthy living spaces by causing environmental pollution.

Science creates a peace environment through the products it develops to meet basic needs (e.g. hunger, thirst, accommodation).

Science cannot contribute to peace through technological advancements by facilitating people's lives while creating threats against their health.

Science education makes a difference for individuals to be able to evaluate international peace strategies by informing them of the developments in the science history.

Individuals' being informed about scientific developments leads them to behave consciously and thus makes a contribution to the world peace.

Science enables people to understand natural events and raises their awareness, which keeps them away from war.

Science education makes a difference for individuals to evaluate national peace strategies by equipping them with the developments in the science history.

Countries are informed about the developments in the world thanks to science. Peace environment is created as the developmental differences between the countries are reduced.

\begin{tabular}{|c|c|c|c|c|}
\hline 2. & 1 & 2 & 3 & 4 \\
\hline 3. & 1 & 2 & 3 & 4 \\
\hline 4. & 1 & 2 & 3 & 4 \\
\hline 5. & 1 & 2 & 3 & 4 \\
\hline 6. & 1 & 2 & 3 & 4 \\
\hline 7. & 1 & 2 & 3 & 4 \\
\hline 8. & 1 & 2 & 3 & 4 \\
\hline 9. & 1 & 2 & 3 & 4 \\
\hline 10. & 1 & 2 & 3 & 4 \\
\hline 11. & 1 & 2 & 3 & 4 \\
\hline 12. & 1 & 2 & 3 & 4 \\
\hline 13. & 1 & 2 & 3 & 4 \\
\hline 14. & 1 & 2 & 3 & 4 \\
\hline 15. & 1 & 2 & 3 & 4 \\
\hline 16. & 1 & 2 & 3 & 4 \\
\hline 17. & 1 & 2 & 3 & 4 \\
\hline 18. & 1 & 2 & 3 & 4 \\
\hline 19. & 1 & 2 & 3 & 4 \\
\hline 20 . & 1 & 2 & 3 & 4 \\
\hline 21. & 1 & 2 & 3 & 4 \\
\hline
\end{tabular}


SEX: $\quad$ DEPARTMENT:

THE SCALE FOR PERCEPTION OF THE RELATIONSHIP BETWEEN SCIENCE AND PEACE (SPSP)

Dear Pre-Service Teachers,

Please indicate your level of agreement with the following expressions by putting a cross $(X)$ in the boxes. Thank you for your contribution to my study with your responses.

\section{Dr. Canan DILEK EREN}

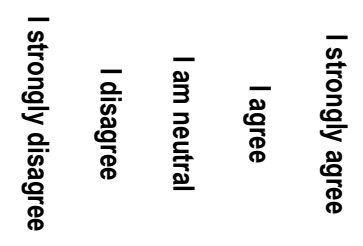

\begin{tabular}{|c|c|c|c|c|c|c|}
\hline $\begin{array}{l}\text { Science creates peace environment by eliminating the poverty through the industrial products it devel- } \\
\text { ops. }\end{array}$ & 22. & 1 & 2 & 3 & 4 & 5 \\
\hline $\begin{array}{l}\text { Science education allows people to come up with peaceful solutions by leading them to adopt a critical } \\
\text { approach towards what is happening around them. }\end{array}$ & 23. & 1 & 2 & 3 & 4 & 5 \\
\hline $\begin{array}{l}\text { Science education allows producing peaceful solutions by improving the problem solving skills of individu- } \\
\text { als. }\end{array}$ & 24. & 1 & 2 & 3 & 4 & 5 \\
\hline $\begin{array}{l}\text { Science contributes to peace by preventing energy wars through the solutions it develops for depleted } \\
\text { energy resources. }\end{array}$ & 25. & 1 & 2 & 3 & 4 & 5 \\
\hline $\begin{array}{l}\text { Science education leads to social peace by making individuals aware of the importance of collaboration- } \\
\text { based working for scientific development. }\end{array}$ & 26. & 1 & 2 & 3 & 4 & 5 \\
\hline
\end{tabular}

Received: May 10, 2016

Accepted: August 02, 2016

Canan Dilek Eren

PhD., Assistant Professor, Education Faculty, Department of Science Education, Kocaeli University, 41380 Kocaeli, Turkey E-mail: canandilek@gmail.com

Website: http://akademikpersonel.kocaeli.edu.tr/canandilek/ 